\title{
Applications of optical descriptors for estimating the amount of sulphur in high viscosity petroleum fractions from the Ashalchinsk oil field
}

\author{
(C) Milana M. Dolomatova, ${ }^{1}$ Rashid I. Hairudinov, ${ }^{1}$ \\ Ella A. Kovaleva, ${ }^{2+}$ and Ildar R. Hairudinov ${ }^{1}$ \\ ${ }^{1}$ Institute of Physics and Technology of Bashkir State University. \\ Zaki Validi St., 32. Ufa, 450074. Bashkortostan Republic. Russia. \\ ${ }^{2}$ Ufa State Petroleum Technological University. Kosmonavtov St., 1 Ufa, 450062. \\ Bashkortostan Republic. Russia.Phone: +7 (917) 406-27-06. E-mail: kovaleva-ugntu@yandex.ru
}

\begin{abstract}
*Supervising author; ${ }^{+}$Corresponding author
Keywords: predictive mathematical model, Ashalchinsk oil, sulphur concentration, boiling point, refractive index.
\end{abstract}

\begin{abstract}
The article proposes a predictive mathematical model to determine the concentration of sulphur in hydrocarbon fractions by the boiling point of the fractions and the refractive index determined by the the sodium yellow line. The model allows for non-linearity of changes in the fractional composition and optical properties with an increase in the amount of sulphur in a multicomponent mixture. Due to the complexity of the multicomponent system, the problem to predict the sulphur concentration was solved using multivariate regression analysis. The model was constructed using a physical and chemical descriptor (boiling point) and an optical descriptor (refractive index). The Ashalchinskoye heavy oil was used as an object for research in this work. The Ashalchinskoye field is one of the most promising fields for industrial development of highviscosity oil in the territory of Republic of Tatarstan. The authors have analyzed the fractional composition and studied the properties of ashalchinsk oil fractions. Methods for determining the fractional composition were carried out according to the ASTM D 2892-18 Standard Test Method for Distillation of Crude Petroleum (15-Theoretical Plate Column) using the fully computer controlled unit "I-Fisher DIST D-2892/5236 CC" in the range from 200 to $400{ }^{\circ} \mathrm{C}$. The refractive index $\mathrm{nD}^{20}$ was determined using an IRF-454B2M multipurpose laboratory refractometer. The sulfur content in oil fractions was determined in accordance with GOST R 51947-02 and ASTM D 4294 by energy dispersive X-ray fluorescence spectroscopy using a sulphur analyzer RX-360SH manufactured by Tanaka Scientific Limited (Japan); for coke residue in accordance with GOST 2059-95 (ISO 351-96) by the POST-2 apparatus manufactured by Millab (Moscow, Russia). In this paper has been made a comparison between the results obtained from regression model and experimental results were for training and testing samples of high-viscosity oil fractions analyzed. Results of numerical studies for Ashalchinsk high-viscosity oil with a high sulphur content demonstrated very good agreement with the experimental data, which suggest adequacy of mathematical model. The data obtained from the model can be used in the preparation of high-viscosity oils for transportation and processing.
\end{abstract}

\section{References}

[1] H. Anchieta. Processing of heavy oil. Reactors and modeling of processes. Trans. from English; Edited by O.F. Glagoleva, V.A. Vinokurov. H. Anchita-St. Petersburg. PSC "Profession". 2015. 592p. (russian)

[2] O.A. Valentinov. Bitumen, close relatives of oil. World energy. 2009. No.1. P.13-15.

[3] I.I. Gussamov, S.M. Petrov, D.A. Ibragimova, G.P. Kayukova, N.Y. Bashkirtseva. Component and Hydrocarbon Composition of Bituminous Oil from Ashalchinskoye Accumulation. Bulletin of Kazan Technological University. 2014. Vol.17. No.10. P.207-211. (russian)

[4] R.I. Khayrudinov, M.Yu. Dolomatov, T.I. Sazhina, I.R. Khayrudinov. Research of the gas generation process during the thermolysis of high-sulphur petroleum feed. World of oil products. The oil companies' bulletin. 2017. No.11. P.4-7. (russian)

[5] R.I. Khayrudinov, M.Yu. Dolomatov, T.I. Sazhina, I.R. Khayrudinov. Thermolysis of high-viscosity oils in order to reduce the viscosity and receive synthetic oil. World of oil products. The oil companies' bulletin. 2018. No.1. P.16-19. (russian) 
APPLICATIONS OF OPTICAL DESCRIPTORS FOR ESTIMATING THE AMOUNT OF SULPHUR IN HIGH... 96-101

[6] R.I. Khairudinov. Features of the process of shallow thermolysis and development of technology for preparation for transportation of high-viscosity oil: Autorefrat dis. Ph. D. Ufa: UGNTU. 2020. 24p. (russian)

[7] M.M. Dolomatova, R.I. Hairudinov, I.R. Hairudinov, M.Yu. Dolomatov, and Z.F. Kuzmina. Relationship between aromatic and naphthenic hydrocarbons amount for fractions of high-viscosity petroleum and integral optical spectral characteristics. Butlerov Communications. 2018. Vol.53. No.2. P.46-52. DOI: 10.37952/ROI-jbc-01/18-53-2-46

[8] M.Yu. Dolomatov, E.A. Kovaleva, K.F. Latypov, M.M. Dolomatova, N.Kh. Paymurzina, and G.U. Yarmuhametova. Integral characteristics of optical spectra, as a new class of descriptors for complex molecular systems. Butlerov Communications. 2019. Vol.57. No.1. P.1-14. DOI: 10.37952/ROI-jbc-01/1957-1-1

[9] M.Yu. Dolomatov, E.A. Kovaleva, K.F. Latypov. Electronic phenomenological spectroscopy and its application in researching complex substances in engineering, chemistry, nanophysics and medicine. Editor professor Dolomatov M.Yu. Part 1. Electronic phenomenological spectroscopy in researching the properties and structure of molecules and nanoparticles: Published by Bashkir State University. Ufa. 2019. 323p. (russian)

[10] S.S. Batsanov. Structural refractometry, 2nd edn. Moscow: High School Press. 1976. 305p. (russian) 